\title{
Glauconite and phosphate peloids in Mesozoic carbonate sediments (Eastern Subbetic Zone, Betic Cordilleras, SE Spain)
}

\author{
J. JIMENEZ-MILLAN, J. M. MOLINA, F. NIETO*, L. NIETO AND \\ P. A. RUIZ-ORTIZ
}

Departamento de Geología, Facultad de Ciencias Experimentales, Universidad de Jaén, Campus Universitario, 23071 Jaén, and *Departamento de Mineralogía y Petrología and IACT, Universidad de Granada-CSIC, Facultad de Ciencias, 18002 Granada, Spain

(Received 22 November 1996; revised 22 July 1997)

\begin{abstract}
Glauconite and Ca phosphate peloids occur in Jurassic and Cretaceous bioclastic carbonate rocks from pelagic swell sequences of the Algayat-Crevillente Unit (Subbetic Zone). The size and morphology of the peloids are controlled by the bioclasts. The glauconite in both stratigraphic positions is $\mathrm{K}$ rich $(>0.69$ atoms p.f.u. $)$ and shows well-defined $10 \AA$ lattice fringes. Poorly crystalline areas with a composition of Fe-smectite are found within the peloids, indicating the nature of the glauconitic precursor. This precursor would be formed in the shielded microenvironments of the bioclast and later transformed to glauconite by equilibration of peloids with sea water that culminated with the crystallization of a phosphatic phase. The greater presence of smectite areas in the Jurassic peloids and the lower K contents $(0.69-0.81)$ of these glauconites, compared with the Cretaceous glauconites $(0.81-0.89)$ can be explained by the calcitic early diagenetic cementation which stopped the process of glauconitization.
\end{abstract}

The green nodular concretions formed in a marine environment and composed mainly of phyllosilicates have generally been called glauconitic peloids. The term glauconite is commonly reserved for the $\mathrm{Fe}$ - and $\mathrm{K}$-rich mica structure mineral, (McRae, 1972; Odin \& Matter, 1981), while the Kpoor terms are commonly known as glaucony (Odin \& Letolle, 1980; Odin \& Matter, 1981; Stille \& Clauer, 1994) or glauconite smectites (Dasgupta et al., 1990; Ostwald \& Bolton, 1992), which correspond to the term nontronite according to Güven (1988). The AIPEA Nomenclature Committee defines glauconite as an Fe-rich dioctahedral mica with tetrahedral $\mathrm{Al}\left(\right.$ or $\mathrm{Fe}^{3+}$ ) usually $>0.2$ atoms p.f.u. and octahedral $R^{3+}>1.2$ atoms (Bailey, 1980). The octahedral sheet consists mainly of $\mathrm{Fe}^{3+}$, which distinguishes glauconite from muscovite and phengite micas. Thus, materials containing an Fe-rich mica as a major component can be called glauconitic micas. Specimens with expandable layers intermixed can be described as randomly interstratified glauconite-smectite (Odom, 1984).

Glauconitization typically occurs in submarine conditions in areas with low sedimentation rate whose depths oscillate between 100 and $300 \mathrm{~m}$. Two hypotheses have been proposed traditionally for the genesis of glauconite: (a) progressive $\mathrm{Fe}$ incorporation into degraded illite structure (Burst, 1958a,b; Hower, 1961); and (b) crystallization of glauconitic smectite in the pores of various framework types (quartz, K-feldspar, biotite, calcitic bioclasts and faecal pellets) concomitant with its progressive dissolution in a confined environment (Odin \& Matter, 1981; Odin \& Fullagar, 1988; Stille \& Clauer, 1994). Later, these particles could 
be modified by $\mathrm{K}$ addition to the smectitic material and the crystallization of phosphatic phases equilibrated with the sea water (Stille \& Clauer, 1994). The glauconitic and phosphatic facies have often been found together in marine formations of very different ages (Odin \& Letolle, 1980; Carson \& Crowley, 1993). Dasgupta et al. (1990) distinguished the processes of glauconitization that imply K-rich frameworks and those which do not.

In the Betic Cordilleras, glauconite has been found in materials related to Mesozoic discontinuities of different ages and in some cases related to phosphatic facies (Debrabant \& Paquet, 1975; Bocchi \& Lucchini, 1991; Martín-Algarra \& Vera, 1994; Vera \& Martín-Algarra, 1994). Martínez-Ruiz (1993) recognized mica of glauconitic composition in the fine fraction of Betic marls, using analytical electron microscopy (AEM).

In this study, we have carried out the compositional and textural characterization of glauconitic peloids in materials associated with two discontinuities from the Algayat-Crevillente Unit (Subbetic Zone, Betic Cordillera), principally using scanning electron microscopy with an energy dispersive system (SEM-EDS) and transmission electron microscopy combined with AEM (TEM-AEM) methods, with the objective to contribute to a better understanding of the processes implied in their genesis.

\section{GEOLOGICAL AND STRATIGRAPHIC SETTING}

Samples of glauconite-bearing rocks were taken from Jurassic and Cretaceous materials of the Algayat-Crevillente Unit, which is located in the eastern part of the Subbetic Zone (province of Alicante, SE Spain) (Fig. 1A). In this unit, the following formations (Fm) were distinguished (Nieto, 1996): (a) Gavilán Fm — dolostones and limestones with a stratigraphic break at the top (D1); (b) Zegrí Fm - rhythmite of limestones and marls with a stratigraphic break (D2) at the top; (c) Veleta Fm - limestones with chert; (d) Upper Ammonitico Rosso Fm - comprising two members, separated by a stratigraphic break (D3), in which the dominant facies are nodular limestones. The Jurassic-Cretaceous stratigraphic break (D4) is located at the top; (e) Carretero Fm marly limestones alternating with marls; (f) Represa Fm — dark (grey or black) marls, limestones and marly limestones with a hardground which result in a stratigraphic break at the top; (h) 'Capas Rojas' Fm - marly limestones alternating with white and pink marls.

The sedimentary rocks with glauconite are located at two stratigraphic levels (Fig. 1B): (1) in a $2-30 \mathrm{~cm}$ thick stratum of green sandy limestone located at the base of the Zegrí Fm and directly on the discontinuity D1 surface. The better outcrops of this bed coincide with palaeokarstic depressions developed at the top of the Gavilán Fm (Sierra of Crevillente). (2) At the top of the Represa Fm, which is observed to the South of the Sierra Algayat (La Canalosa outcrop), in a $50 \mathrm{~cm}$ thick stratum which, in its upper part, has a bioturbated hardground covered by a fine plate of Fe oxides and limonite.

\section{METHODS}

Initial studies were made of the petrography and mineral composition of 50 rocks associated with the stratigraphic breaks of the area using optical microscopy, X-ray powder diffraction (XRD) and SEM with EDS microanalyser. On the basis of these previous studies, seven samples were chosen for the TEM and the high-resolution transmission electron microscopy (HRTEM) study: four samples from the Jurassic discontinuity and three samples from the Cretaceous discontinuity.

In order to obtain the pure glauconite peloids, samples were disaggregated and washed on a $100 \mu \mathrm{m}$ screen. The peloids were separated magnetically in the first stage. They were concentrated further by handpicking. The $<2 \mu \mathrm{m}$ clay fraction of this concentrate was separated by sedimentation techniques in selected samples which were treated with ethylene glycol and also heated. Chemical treatment was not used in order to avoid alteration of the clay particles. The XRD data were obtained from powders and oriented aggregates with a Siemens D-5000 Diffractometer using $\mathrm{Cu}-K \alpha$ radiation and a $\mathrm{Ni}$ filter between 2 and $70^{\circ}$ at a speed of $1.2^{\circ} 2 \theta / \mathrm{min}$.

The SEM study was made on polished samples with a Zeiss DSM-950 electron microscope equipped with a Link QX2000 microanalyser. Albite, orthoclase, periclase, wollastonite and synthetic oxides $\left(\mathrm{Al}_{2} \mathrm{O}_{3}, \mathrm{Fe}_{2} \mathrm{O}_{3}\right.$ and $\left.\mathrm{MnTiO}_{3}\right)$ were used as calibration standards. The analytical data were ZAF corrected. Due to the very fine grain size of the samples, it was necessary to do a careful selection of the spots to be analysed using 


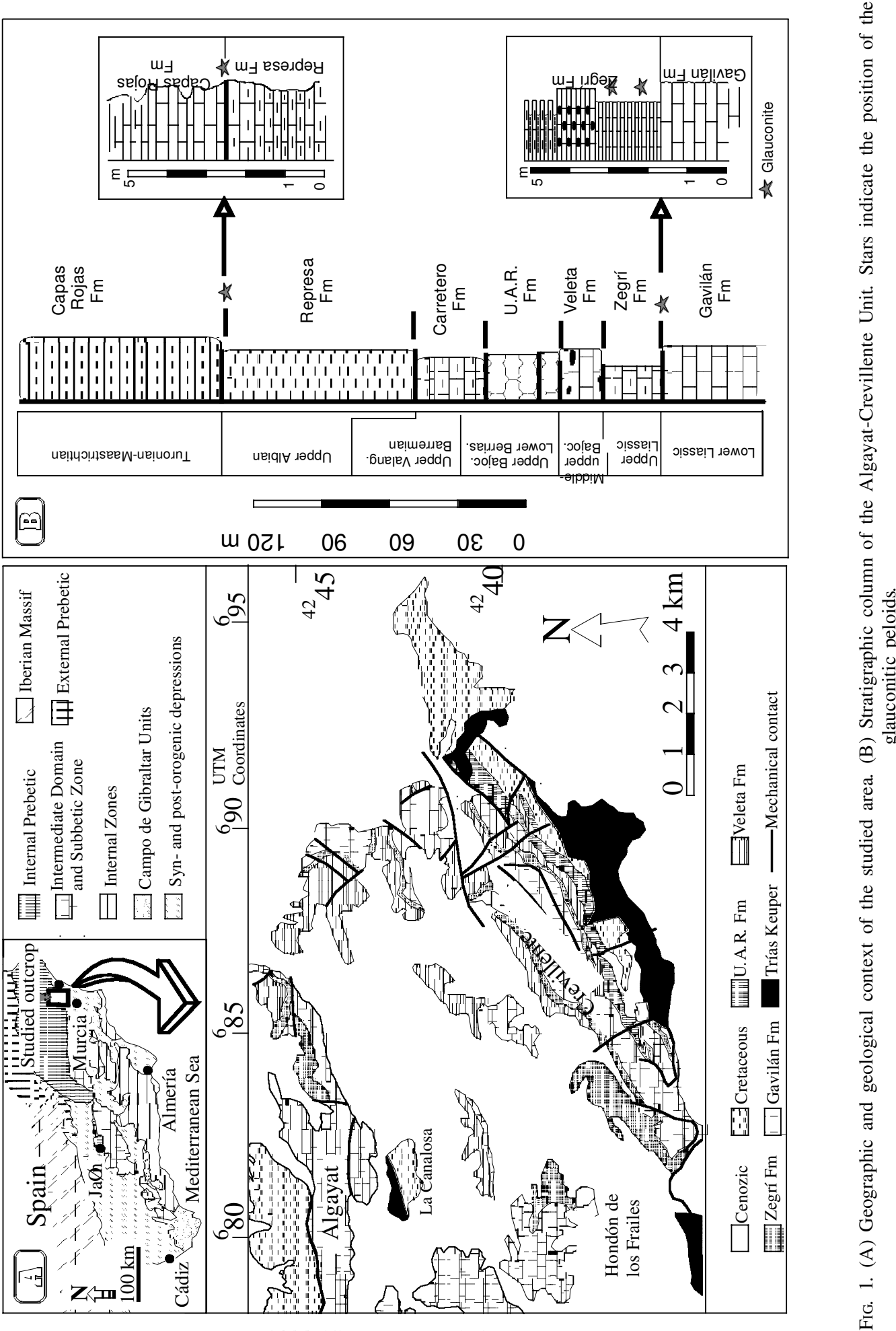



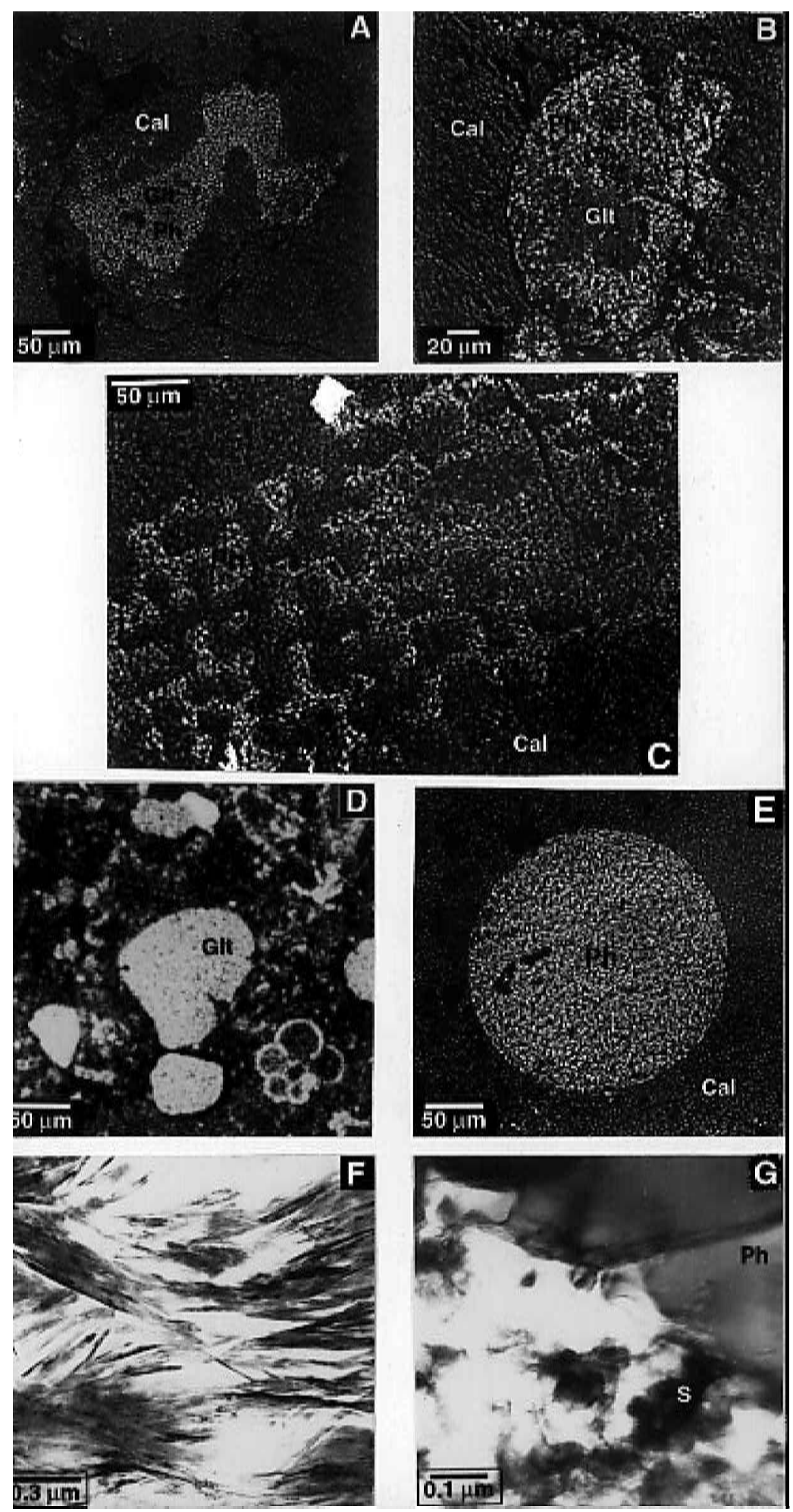
backscattered electron images in the atomic number contrast mode.

The TEM and HRTEM studies were carried out with a Philips CM-20 scanning transmission electron microscope (STEM) working at $200 \mathrm{kV}$ accelerating voltage. The point-to-point resolution of this apparatus is $2.7 \AA$ in TEM mode and $50 \AA$ in STEM mode. For observations in STEM mode, samples were tilted by $20^{\circ}$ toward the X-ray detector. Copper rings were attached to representative selected areas of thin-sections. These areas were detached through gentle heating. Samples were further thinned with a Gatan dual ion mill using an accelerating voltage of $6 \mathrm{kV}$ during three stages: (a) incidence angle of $15^{\circ}$ and probe current of $1 \mathrm{nA}$; (b) incidence angle of $15^{\circ}$ and probe current of $0.6 \mathrm{nA}$; and (c) incidence angle of $12^{\circ}$ and probe current of $0.4 \mathrm{nA}$. Chemical analyses of particles were made using STEM mode with an EDAX microanalysis system. A $200 \times 1000 \AA$ scanning area with the long axis oriented parallel to phyllosilicate packets was used for each analysis using a $50 \AA$ beam diameter. Counting times of $200 \mathrm{~s}$ were used except for $\mathrm{Na}$ and $\mathrm{K}$, which were analysed using $30 \mathrm{~s}$ counting times. Albite, olivine, biotite, spessartine, muscovite, chlorite and titanite were used to obtain k-factors for transformation of intensity ratios to concentration ratios according to the Cliff \& Lorimer (1975) approximation. We considered that $\mathrm{Fe}$ was present as $\mathrm{Fe}^{3+}$.

\section{PETROGRAPHY AND TEXTURE OF THE GLAUCONITE-BEARING ROCKS}

\section{Zegrí Formation}

From a textural point of view, the limestones with glauconite located at the bottom of the Zegrí Fm (on D1) are crinoidal packstone or grainstone, though foraminifera (Valvulina, Nodosariidae) faecal pellets and sponge spicules are also found.
In the packstone microfacies, $100-300 \mu \mathrm{m}$-sized allochemicals are partially included in a micritic matrix. In the grainstone type texture, crinoids are of greater size $(250-600 \mu \mathrm{m})$ and they develop a cloudy texture showing overgrowths of a syntaxial calcite cement. Some samples contain up to $10 \%$ dolomite. In all of the materials from the Zegrí Fm, we have observed brownish green glauconite and $\mathrm{Ca}$ phosphate aggregates of various sizes and morphologies. The size of the peloids is directly related to the size of the crinoid fragments of the sediment, so that the samples with larger crinoids (grainstone) contain larger glauconitic peloids. With regard to the morphology, according to the classification of Odin \& Fullagar (1988) the most abundant habits are internal moulds developed on crinoidal substrates, as can be seen in Fig. 2A where the peloid has the shape of a crinoid fragment. Radial cracks were not observed. Phosphate is not present in all the peloids. Approximately half of the peloids are characterized by the presence of a phosphatic phase, which commonly occupies the outer zone of the peloids surrounding a core that consists of glauconitic material (Fig. 2B). In some peloids the crystallization of phosphate is restricted to the walls separating crinoid chambers (see left side of Fig. 2C). Textural evidence shows that after initial crystallization in the walls, phosphate grows toward the interior of the bioclast chambers (see right Fig. 2C). Finally, it is interesting to underline that in the grainstone, all the peloids are included in the syntaxial calcitic cement (Fig. 2A).

\section{Represa Formation}

Petrographically, the limestones from the upper stratum of the Represa Fm are wackestone showing planktonic foraminifera (Rotalipora apenninica RENZ), calcispheres (Stomiosphaera sphaerica KAUFMAN), faecal pellets, echinoderm plates and other bioclasts. The matrix is bioturbated and

FIG. 2. Petrographic and textural features of the glauconitic peloids studied. (A) SEM backscattered electron image (BSI) of a crinoid bioclast filled by glauconite and apatite, and cemented by syntaxial calcite. (B) SEMBSI that shows the zoned internal texture of a peloid consisting of a glauconitic core surrounded by a mixture of phosphatic and glauconitic material. (C) SEM-BSI of glauconite and apatite crystallized in the walls and within the bioclast chambers. (D) Micrograph showing the typical shape of a peloid resembling that of planktonic foraminifera. (E) Spherical phosphate peloid. (F) TEM low-magnification image showing the characteristic lamellar texture of glauconite. (G) TEM low-magnification image showing Ca sulphate nodular concretions in the rim of a peloid. Mineral abbreviations: $\mathrm{Cal}=$ calcite, $\mathrm{Glt}=$ glauconite, $\mathrm{Ph}=\mathrm{Ca}$ phosphate, $\mathrm{S}=\mathrm{Ca}$ sulphate. 
also partially silicified to microcrystalline xenomorphic quartz. Scattered grains of albite and red $\mathrm{Fe}$ oxides have been observed. Glauconite is located in green peloids $(300-500 \mu \mathrm{m}$ in size) showing spherical or subrounded morphologies. Peloids with smooth external surfaces are as abundant as those showing radial cracks along the periphery (Fig. 2D), which suggests that they can be classified as evolved or highly evolved peloids. The mineral composition of peloids consists mainly of glauconite and $\mathrm{Ca}$ phosphate. The greater the proportion of apatitic material, the lighter the peloid. In fact, some colourless peloids of $\mathrm{Ca}$ phosphate were found (Fig. 2E). The glauconite-rich peloids display a widespread and characteristic lamellar texture. Low magnification micrographs (TEM) (Fig. 2F) show that the lamellae appear to consist of a spindle-shaped arrangement of layered crystallite packets. Rims of some peloids are characterized by the presence of $\mathrm{Ca}$ sulphate nodular concretions intergrown with the Ca-phosphate-glauconite material (Fig. 2G).

\section{XRD, HRTEM AND COMPOSITIONAL DATA}

The XRD patterns from most of the Cretaceous peloids reveal narrow 001 reflections of glauconite at $10 \AA$. The intensity of this peak is increased slightly after ethylene glycol solvation and heating, which suggests the presence of a small number of expandable layers. In addition, the sharp and symmetric 020 and 130 reflections and the well developed 112 and $11 \overline{2}$ reflections indicate a predominantly ordered structure. Jurassic peloids show XRD patterns having slightly more asymmetric $10 \AA$ peaks in which ethylene glycol solvation produced little change, but heat treatment increased the intensity of reflections and diminished broadening. Furthermore, weak, broad peaks between 12 and $14 \AA$ were observed, which disappeared after heating and were found at $17 \AA$ after ethylene glycol solvation. These data indicate the presence of material having layer spacings $>10 \AA$. In these samples, the small number of diffractions observed as well as the low intensity of 112 and $11 \overline{2}$ peaks can be indicative of structural disorder. With regard to the phosphate phase, XRD indicates that in Jurassic and Cretaceous peloids, a carbonate-fluorapatite is present.

Most of the studied Jurassic and Cretaceous peloids present HRTEM images consisting of well- defined $10 \AA$ lattice fringes of spindle glauconite crystals (Fig. 3A,B) and SAED patterns of $10 \AA$ periodicity (Fig. 3C). Cretaceous peloids rarely show HRTEM images of poorly crystalline zones, although a few zones with $12.5 \AA$ planes are observed (Fig. 3A). On the other hand, considerable areas of the Jurassic peloids are characterized by the presence, in the HRTEM images, of poorly organized zones where lattice fringe images are difficult to obtain (Fig. 3D). The fringes of these zones are discontinuous with the variation of the interplanar spacing between 10 and $14 \AA$. The poorly organized zones produce spotty SAED patterns which display periodicity of $\sim 14 \AA$ indicating the existence of a smectitic material (Fig. 3E).

Micro-chemical analyses of the studied peloids are in agreement with the XRD and HRTEM data. Thus, the amount of interlayer $\mathrm{K}$ after EDS-SEM analyses is always $>0.719$ atoms p.f.u. in the normalized formula to $\mathrm{O}_{10}(\mathrm{OH})_{2}$ (Table 1), which allows its classification as glauconite, according to the definition recommended by AIPEA (Bailey, 1980). The compositional range of the octahedral sheet of the Cretaceous and Jurassic glauconites is characterized by high Fe content $(0.89-1.35$ atoms p.f.u.) and low $\mathrm{Al}(0.20-0.65)$ and $\mathrm{Mg}(<0.50)$ contents. The $\mathrm{Al}, \mathrm{Mg}$ and $\mathrm{Fe}$ contents are within the range of typical contents for these elements, e.g. Chamley (1989) and Velde (1992). The glauconite composition shows no significant variation between the periphery and the central portions of the peloids. However, considerable differences in $\mathrm{K}$ content between glauconites from both stratigraphic levels have been observed. In the Cretaceous rocks, the EDS-SEM and AEM analyses of glauconite reveal $\mathrm{K}$ contents ranging from $0.80-0.89$ atoms p.f.u. These contents are greater than those of the glauconites from the Jurassic peloids, where AEM analyses of crystalline areas, with well-defined $10 \AA$ lattice fringes, have $\mathrm{K}$ contents of between 0.69 and 0.77 atoms p.f.u., which are similar to those obtained by EDSSEM (0.719-0.809 atoms p.f.u.) (Fig. 4). Furthermore, AEM analyses of the poorly organized areas with discontinuities reveal an $\mathrm{Fe}$ smectite composition (Table 2, Fig. 4). Thompson \& Hower (1975) showed the relationship between the glauconite $\mathrm{K}$ content and the proportion of smectite layers in the interstratified structure. According to the model proposed by these authors, the glauconites studied present a glauco- 

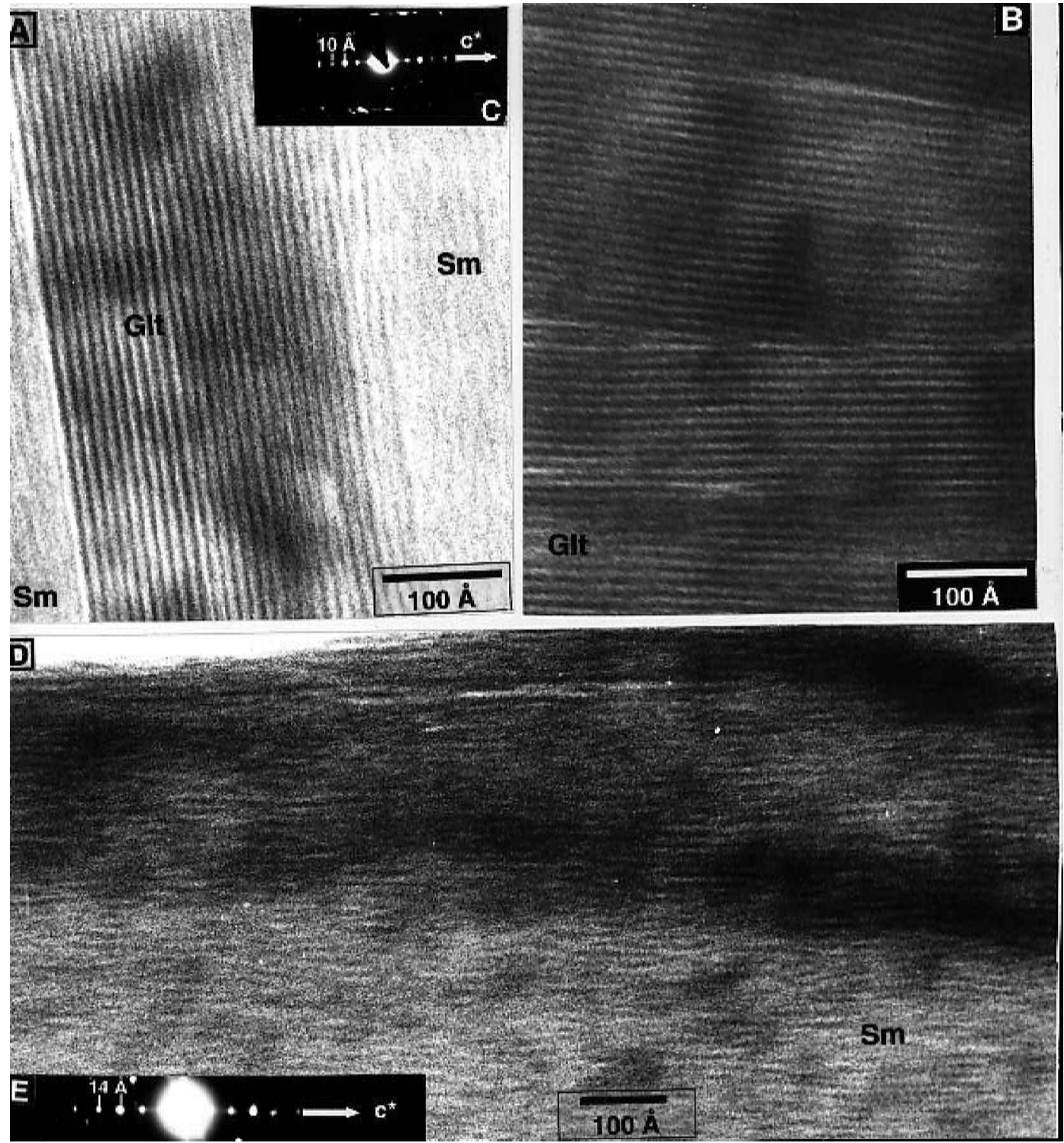

FIG. 3. (A) Well-defined $10 \AA$ lattice fringes of glauconite crystal and two areas of smectitic material. (B) HRTEM image of glauconite crystals with well-defined $10 \AA$ lattice fringes. (C) Typical SAED image of glauconite. (D) Poorly crystalline zones of smectitic material. (E) SAED pattern of these areas. Mineral abbreviations: Glt $=$ glauconite, $\mathrm{Sm}=$ smectite.

nitic layer proportion between 92 and $95 \%$ in the Jurassic peloids and $>95 \%$ in the Cretaceous peloids. The EDS-SEM analyses of the carbonatefluorapatite show that the chemical composition of the studied Jurassic and Cretaceous phosphates compare reasonably well with the estimation of marine carbonate fluorapatite (see McArthur, 1985) in which $\mathrm{CaO} / \mathrm{P}_{2} \mathrm{O}_{5}$ ratio is $\sim 1.55$ and the $\mathrm{Na}_{2} \mathrm{O}$ content is $<1.60 \%$ (Table 3 ). The presence of $\mathrm{F}$ was qualitatively detected. 
TABLE 1. Representative SEM-EDS data for glauconite normalized to $\mathrm{O}_{10}(\mathrm{OH})_{2}$.

\begin{tabular}{llllllll}
\hline & $\mathrm{Si}$ & $\mathrm{Al}^{\mathrm{IV}}$ & $\mathrm{Al}^{\mathrm{VI}}$ & $\mathrm{Mg}$ & $\mathrm{Fe}$ & $\Sigma^{\mathrm{VI}}$ & $\mathrm{K}$ \\
\hline 1 & 3.593 & 0.407 & 0.645 & 0.504 & 0.912 & 2.06 & 0.729 \\
2 & 3.591 & 0.409 & 0.454 & 0.442 & 1.132 & 2.028 & 0.766 \\
3 & 3.566 & 0.434 & 0.381 & 0.366 & 1.255 & 2.002 & 0.795 \\
& & & & & & & \\
4 & 3.534 & 0.466 & 0.492 & 0.383 & 1.139 & 2.014 & 0.809 \\
5 & 3.499 & 0.501 & 0.41 & 0.43 & 1.215 & 2.055 & 0.765 \\
6 & 3.624 & 0.376 & 0.528 & 0.457 & 1.031 & 2.015 & 0.786 \\
7 & 3.677 & 0.323 & 0.217 & 0.436 & 1.319 & 1.973 & 0.841 \\
8 & 3.726 & 0.274 & 0.293 & 0.43 & 1.239 & 1.962 & 0.819 \\
9 & 3.691 & 0.309 & 0.208 & 0.393 & 1.344 & 1.945 & 0.868 \\
& & & & & & & \\
\hline
\end{tabular}

1 to 3: Glauconite from peloids in Jurassic packstone facies.

4 to 6: Glauconite from peloids in Jurassic grainstone facies.

7 to 9: Glauconite from peloids in Cretaceous wackstone facies.

\section{DISCUSSION}

\section{Sedimentary conditions}

The studied glauconites occur in two stratigraphic levels originating in similar sedimentary conditions. Samples from the Represa Fm are located at the top of a pelagic swell stratigraphic sequence covered by a hardground. The planktonic foraminifera were better adapted to these shallow water conditions. On the other hand, the samples of the Zegrí Fm are located

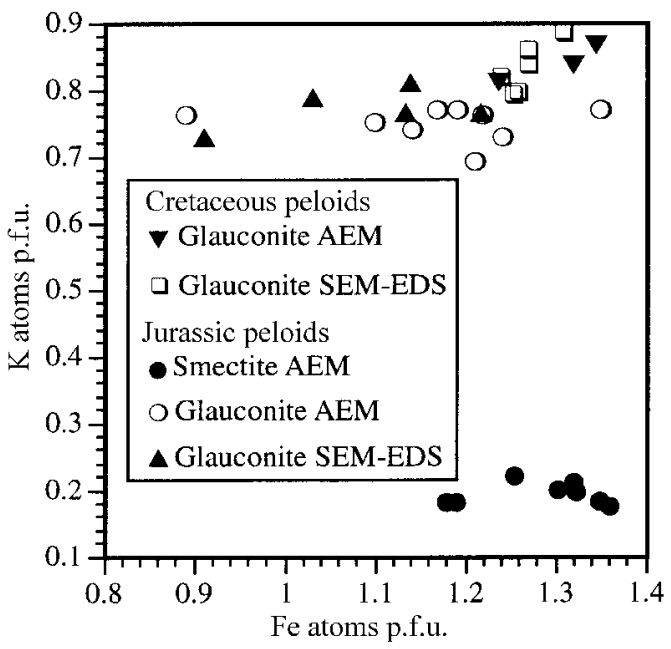

FIG. 4. Potassium and Fe contents of the Jurassic and Cretaceous glauconitic materials studied. on the bottom of a swell transgressive sequence with shallow sedimentation. In this case, crinoids were the more abundant fossils, because of the environmental conditions. In both situations, the sedimentary conditions led to the deposition of granular-porous materials because of the abundance of carbonated bioclasts with internal chambers. Thus, a starved sedimentary environment with low rate of detrital deposits and numerous partially isolated microenvironments was originated, producing an ion concentration greater than that of open marine water. Figure 2 shows that these bioclasts constituted adequate physical frameworks to create microenvironments with favourable chemical conditions for the glauconitization and phosphatization processes. Feldspar clasts with glauconitic alteration, similar to those described by Dasgupta et al. (1990), Chaudhuri et al. (1994) and Rawlley (1994) have not been observed in the studied samples. Therefore, an original K-rich framework for the glauconite formation may be discarded In our case, the existence of partially isolated microenvironments must have been fundamental for the development of glauconitization and phosphatization processes because the proportion of glauconite peloids is directly related to the number of bioclasts in the rocks.

\section{Processes of glauconitization and phosphatization}

Textural evidence from the studied samples shows that glauconitization and phosphatization 
TABLE 2. Representative AEM data for studied glauconitic materials normalized to $\mathrm{O}_{10}(\mathrm{OH})_{2}$.

\begin{tabular}{|c|c|c|c|c|c|c|c|c|c|}
\hline & $\mathrm{Si}$ & $\mathrm{Al}^{\mathrm{IV}}$ & $\mathrm{Al}^{\mathrm{VI}}$ & $\mathrm{Mg}$ & $\mathrm{Fe}$ & $\Sigma^{\mathrm{VI}}$ & $\mathrm{Ca}$ & $\mathrm{Na}$ & $\mathrm{K}$ \\
\hline 1 & 3.83 & 0.17 & 0.41 & 0.52 & 1.14 & 2.07 & 0.05 & 0.05 & 0.18 \\
\hline 2 & 3.90 & 0.10 & 0.34 & 0.44 & 1.30 & 2.08 & 0.01 & 0.02 & 0.21 \\
\hline 3 & 3.85 & 0.15 & 0.40 & 0.47 & 1.25 & 2.12 & 0.01 & 0.02 & 0.22 \\
\hline 4 & 3.80 & 0.20 & 0.48 & 0.30 & 1.30 & 2.08 & 0.02 & 0.02 & 0.20 \\
\hline 5 & 3.78 & 0.22 & 0.39 & 0.37 & 1.36 & 2.12 & 0.02 & 0.01 & 0.18 \\
\hline 6 & 3.84 & 0.16 & 0.44 & 0.54 & 1.18 & 2.16 & 0.01 & 0.01 & 0.19 \\
\hline 7 & 3.81 & 0.19 & 0.47 & 0.28 & 1.32 & 2.07 & 0.03 & 0.00 & 0.20 \\
\hline 8 & 3.79 & 0.21 & 0.40 & 0.36 & 1.35 & 2.11 & 0.01 & 0.04 & 0.18 \\
\hline 9 & 3.63 & 0.37 & 0.35 & 0.50 & 1.21 & 2.06 & - & - & 0.69 \\
\hline 10 & 3.59 & 0.41 & 0.40 & 0.44 & 1.19 & 2.03 & - & - & 0.77 \\
\hline 11 & 3.63 & 0.37 & 0.44 & 0.45 & 1.14 & 2.03 & - & - & 0.74 \\
\hline 12 & 3.60 & 0.40 & 0.42 & 0.37 & 1.22 & 2.00 & - & - & 0.76 \\
\hline 13 & 3.63 & 0.37 & 0.38 & 0.40 & 1.24 & 2.01 & - & - & 0.73 \\
\hline 14 & 3.52 & 0.48 & 0.46 & 0.41 & 1.17 & 2.04 & - & - & 0.77 \\
\hline 15 & 3.61 & 0.39 & 0.52 & 0.43 & 1.10 & 2.06 & - & - & 0.75 \\
\hline 16 & 3.67 & 0.33 & 0.20 & 0.45 & 1.35 & 2.00 & - & - & 0.77 \\
\hline 17 & 3.62 & 0.38 & 0.65 & 0.50 & 0.89 & 2.04 & - & - & 0.76 \\
\hline 18 & 3.71 & 0.29 & 0.27 & 0.44 & 1.26 & 1.98 & - & - & 0.80 \\
\hline 19 & 3.68 & 0.32 & 0.27 & 0.44 & 1.27 & 1.97 & - & - & 0.84 \\
\hline 20 & 3.72 & 0.28 & 0.29 & 0.43 & 1.24 & 1.96 & - & - & 0.82 \\
\hline 21 & 3.67 & 0.33 & 0.25 & 0.45 & 1.27 & 1.97 & - & - & 0.86 \\
\hline 22 & 3.64 & 0.36 & 0.22 & 0.44 & 1.31 & 1.97 & - & - & 0.89 \\
\hline
\end{tabular}

1-8: Smectite-rich areas from Jurassic peloids.

9-17: Glauconite from Jurassic peloids.

18-22: Glauconite from Cretaceous peloids.

are restricted inside older bioclasts and therefore these processes should develop in a microenvironment essentially shielded from the open marine water. The presence of crinoid bioclasts replaced by a glauconitic core and a $\mathrm{Ca}$ phosphate rim reveals that the process of phosphatization was produced in a stage subsequent to the begining of glauconitiza-

TABLE 3. Representative SEM-EDS data for phosphates in the Jurassic and Cretaceous glauconite-phosphate peloids.

\begin{tabular}{lcccc}
\hline & $\mathrm{P}_{2} \mathrm{O}_{5}$ & $\mathrm{CaO}$ & $\mathrm{MgO}$ & $\mathrm{Na}_{2} \mathrm{O}$ \\
\hline 1 & 31.70 & 49.71 & 0.42 & 1.54 \\
2 & 32.56 & 50.22 & 0.33 & 1.52 \\
3 & 33.68 & 51.55 & 0.41 & 1.58 \\
4 & 32.90 & 51.65 & 0.40 & 1.58 \\
\hline
\end{tabular}

1 and 2: Phosphates from Jurassic peloids.

3 and 4: Phosphates from Cretaceous peloids. tion. Odin \& Letolle (1980) indicated that glauconitization may be followed by phosphatization in the normal evolution of a basin. Bocchi \& Lucchini (1991) found textural relationships between glauconite and $\mathrm{Ca}$ phosphate similar to that described in this work in the Mesozoic phosphorites of the Penibetic Domain. This is in accordance with some aspects of the two step glauconitization model (Odin \& Fullagar, 1988; Clauer et al., 1992; Stille \& Clauer, 1994).

The first glauconitization step is characterized by the formation of a glauconitic precursor. However, the nature of this precusor is widely debated. Odin \& Fullagar (1988) suggested that during this initial stage, crystal growth of an $\mathrm{Fe}$-smectite was produced in the framework pores using cations from sea and interstitial waters. However, Clauer $e t$ al. (1992) and Stille \& Clauer (1994) proposed the existence of a clay glauconitic precursor that chemically dominates the environment. Galán et al. (1995) have proposed that this precursor could be a rich kaolinite-smectite bearing substratum for 
glauconitic micas from Miocene detrital sediments of the SW Guadalquivir basin. The precursor undergoes dissolution-recrystallization processes until a material containing $4.5 \% \mathrm{~K}_{2} \mathrm{O}$ is obtained (Clauer et al., 1992; Stille \& Clauer, 1994). On HRTEM and AEM analyses, Amouric \& Parron (1985) and Amouric (1990) have suggested that the earliest stage of glauconitization is the formation of a gel from which a $12.5 \AA$ smectite (of Fe-beidellite or Fe-montmorillonite type) phase is formed. Also, Martín Algarra \& Sánchez Navas (1995) suggest the deposit of a non-crystalline Fe-Al-Si-rich precursor in phosphate stromatolites from which a smectite glauconite clay is crystallized. Our HRTEM, XRD and compositional data reveal the presence of poorly crystalline material with smectite composition among spindle arrangement lamellae that could represent the remains of the glauconitic precursor from which glauconite was crystallized. Although we have not observed the presence of a gel phase, the extremely poor crystallinity of some smectite areas suggests that their origin might be related to the previous existence of a gel. Amouric (1990) indicated that the presence of a smectite phase represents an intermediate step in the process of glauconitization from the precursor gel.

During the second step (maturation stage), microenvironments are opened to marine influences that produce an increase in the $\mathrm{K}$ content of the previously formed material. Odin (1975) and Clauer (1976) suggested that products with $>6.5 \% \mathrm{~K}_{2} \mathrm{O}$ are in equilibrium with the depositional environment. In the model of Amouric \& Parron (1985), glauconite growth takes place via non-crystalline zones caused by a progressive destabilization of the $12.5 \AA$ phase. The compositional and HRTEM characteristics of the studied glauconites confirm the performance of the second stage of the process. In this way, its high $\mathrm{K}$ contents, always $>0.69$ atoms p.f.u. (Table 1), and the abundance of particles having regular $10 \AA$ spacings indicate a good degree of maturation and equilibrium with the Jurassic and Cretaceous sea waters. Before proposing the mechanism of transformation of smectite to glauconite, the following points must be taken into account: (a) we have not seen the transitional relationships between smectite and glauconite described by Amouric \& Parron (1985) and Amouric (1990), possibly because such zones are very difficult to image as they are very quickly beam-damaged; (b) neither have we observed interlayering of smectite-glauconite; (c) all the levels (T,O,T,I) in layers of smectite and glauconite are quite different and therefore the transformation process cannot be reduced to a simple $\mathrm{K}$ increase at the interlayer level. These considerations lead us to suggest that glauconite could be formed from the smectitic precursor through decomposition-crystallization (neoformation) processes as those proposed by Amouric \& Parron (1985) and Amouric (1990). Nevertheless, we have observed that the glauconite and smectite layers are sub-parallel to each other, which could result as a consequence of topotactic replacement.

On the other hand, Stille \& Clauer (1994) showed that the formation of a phosphatic phase during the maturation stage of the glauconitic pellets approximates its isotopic composition to that of the sea water. The existence of an abundant phosphatic phase in most of the studied glauconitic peloids agrees with the hypothesis proposed by Stille \& Clauer (1994) and reveals a wide extension of the sea-water effect. The presence of dissolution features on carbonate bioclast frameworks indicates lower $\mathrm{pH}$ conditions in these substrata before or during the phospate precipitation (Jarvis, 1992). Prévôt \& Lucas (1986) have shown in experimental phosphatization processes of foraminifera, that apatite replaces carbonate shells and later, neoformed apatitic fingers extend from the walls growing towards the interior of the chambers and progressively filling up these chambers. This is in agreement with the observed textures in the studied samples. The crystallization of apatite replacing the shells as well as apatite filling the chambers has usually been considered as being controlled by bacterial activity. However, we have not found any textural evidence supporting a microbial origin for the deposits of phosphates, such as colloform morphologies or the presence of black organic remains. Van Capellan \& Berner (1991) demonstrated experimentally inorganic precipitation of fluorapatite from common marine solutions. Experimental studies (Krajewsky et al., 1994) have shown the previous deposit of an amorphous phosphatic phase that later recrystallizes to apatite. However, textural and mineral data of the studied samples do not reveal the presence of this precursor.

Finally, the presence of spherulitic $\mathrm{Ca}$ sulphates restricted to the peloids confirms that the conditions were above the sulphide reduction zone and it indicates the very high salinity of the microenvir- 
onment inside the peloid $(0.015 \mathrm{M} \mathrm{NaCl}$ solution $)$ as compared with the open sea-water salinity (0.002 м) (Cody \& Hull, 1980; Møller, 1988).

\section{Effect of the degree of maturation}

The degree of maturation must influence the compositional and textural features of the glauconitic materials. As commented above, from a chemical point of view the most discriminating parameter is the $\mathrm{K}$ content of the glauconitic materials, showing all the studied glauconites at a very high degree of maturation. Amorosi (1995) has shown that glauconites from hardground of condensed sections have a very high degree of maturation. However, it must be pointed out that glauconites from the Jurassic Zegrí Fm samples show $K$ values (0.69-0.81) slightly lower than those of the Cretaceous glauconites (0.80-0.89). Further, as demonstrated by HRTEM, the greater presence of poorly crystalline smectitic materials in the Jurassic peloids, and the petrographic evidence of a stronger phosphatization in the samples of the Cretaceous Represa Fm, which show more evolved morphologies than Jurassic peloids, must be considered. Taking into account these compositional and textural data, it can be concluded that in the samples from the Zegrí Fm, the process of seawater influence (second step of glauconitization) could have been stopped before completion. The presence of crinoid bioclasts cemented by syntaxial calcite (Fig. 2A) suggests that the crystallization of this cement could account for the loss of porosity in the sediment, which made the flow of sea water into the sediment difficult. This fact could facilitate the stopping of the process of equilibration of the glauconitic material with the sea water. Strickler \& Ferrell (1990) observed in the glauconites of the First Wilcox sandstone of Louisiana that the K content was greater in non-cemented samples than in samples with a ferrous calcite cement.

\section{CONCLUSIONS}

The studied glauconites are located in condensed sequences deposited in a pelagic swell environment characterized by low sedimentation rate and abundant porous bioclasts. The petrographic study demonstrated that the proportion, size and morphology of the bioclasts, supposed to be fundamental for the development of glauconitization processes because the features of glauconite peloids, are directly related to those of the porous bioclasts.

The detection by HRTEM and XRD of poorly crystalline materials within the peloids suggests that a possible glauconitic precursor should be formed in the shielded microenvironments of the bioclast chambers as an Fe-smectite, which could be crystallized from a gel-like material. Based on the absence of interlayered smectite-glauconite and the structural differences between these minerals, it is proposed that glauconite was formed from the smectitic precursor by a decomposition-crystallization process, while the shielded microenvironments were progressively opened until the crystallization of a K-Fe-rich phyllosilicate together with a phosphatic phase occurred due to the effect of the open marine water.

High K contents, HRTEM micrographs showing the abundant glauconite crystallites having regular $10 \AA$ Apacings, narrow XRD peaks and the evolved morphologies of the grains indicate a high degree of maturation in the glauconitization of the studied Cretaceous peloids. However, slightly lower K content in glauconite, the greater presence of smectite areas and broader XRD peaks in the Jurassic peloids can be explained by the early calcitic diagenetic cementation, which stopped the process of equilibration of glauconitic material with the sea water.

\section{ACKNOWLEDGMENTS}

The authors are very grateful to $\mathrm{Dr} \mathrm{M}$. Amouric (CRMCC, Marseille) and an unnamed referee for their very useful suggestions. We thank the CIC (Univ. Granada) and the STI (Univ. Jaén) for the use of their instrumental techniques. Financial support was provided by the Research Groups 4065 and 4135 of the Junta de Andalucía and the Projects PB92-0961 and PB93-1150-CO2 of DGICYT. We are grateful to Prof. Roxanne Brewer for linguistic assistance.

\section{REFERENCES}

Amorosi A. (1995) Glaucony and sequence stratigraphy: a conceptual framework of distribution in siliciclastic sequences. J. Sed. Res. 65, 419-425.

Amouric M. (1990) La transformation gel $\rightarrow$ smectite $\rightarrow$ glauconite. Pp. 451-461 in: Matériaux Agileux: Structure, Propriétés et Applications (A. Decarreau, editor) Soc. Franc. Minér. Cristal.

Amouric M. \& Parron C. (1985) Structure and growth mechanism of glauconite as seen by high-resolution 
transmission electron microscopy. Clays Clay Miner. 33, 473-482.

Bailey S.W. (1980). Summary of recommendations of AIPEA Nomenclature Committee. Clay Miner. 15, $85-93$.

Bocchi G. \& Lucchini F. (1991) Caratterizzazione mineralogica e geochimica di fosforiti mesozoiche del Penibético (Spagna meridionale). Miner. Petro. Acta, 34, 121-131.

Burst J.F. (1958a) Glauconite pellets: their mineral nature and applications to stratigraphic interpretations. Bull. Am. Ass. Petrol. Geol. 42, 310-327.

Burst J.F. (1958b) Mineral heterogeneity in glauconite pellets. Am. Miner. 43, 481-497.

Carson G.A. \& Crowley S.F. (1993) The glauconitephospahate association in hardgrounds: examples from the Cenomanian of Devon, southwest England. Cret. Res. 14, 69-89.

Chaudhuri A.K., Chanda S.K. \& Dasgupta S. (1994) Proterozoic glauconitic peloids from South India: their origin and significance. J. Sed. Res. 64, $765-770$.

Chamley H. (1989) Clay Sedimentology. Springer, Berlin.

Clauer N. (1976) Geochimie isotopique du strontium des milieux sédimentaires. Application á la géochronologie de la coverture du craton ouest-africain. Sci. Géol. Chém., Strasbourg, 45, 256 pp.

Clauer N., Stille P., Keppens E. \& O'Neil J.R. (1992) Le mécanisme de la glauconitisation: apports de la géochimie isotopique du strontium, du néodyme et de l'oxygène de glauconies récentes. C. R. Acad. Sci. Sér. II, 315, 321-327.

Cliff G. \& Lorimer G.W. (1975) The quantitative analysis of thin specimens. J. Microsc. 103, 203-207.

Cody R.D. \& Hull A.B. (1980) Experimental growth of primary anhydrite at low temperatures and water salinities. Geology, 8, 505-509.

Dasgupta S., Chaudhuri A.K. \& Fukuoka M. (1990) Compositional characteristics of glauconitic alterations of K-feldspar from India and their implications. J. Sed. Pet. 60, $277-281$.

Debrabant P. \& Paquet J. (1975) L'association glauconites-phosphates-carbonates (Albien de la Sierra de Espuña, Espagne Méridionale). Chem. Geol. 15, $61-75$.

Galán E., González I., Mayoral E. \& Muniz F. (1995) Contribution of clay mineralogy to the paleoenvironmental interpretation of upper miocene detrital sediments. Southwestern of the Iberian Peninsula. Pp. 311-312 in: Euroclay'95, Book of Abstracts (A. Elsen, P. Grobet, M. Keung, H. Leeman, R. Schoonheydt \& H. Toufar, editors).

Güven N. (1988) Smectites. Pp. 497-559 in: Hydrous Phyllosilicates (S.W. Bailey, editor) Reviews in Mineralogy, 19. Mineral. Soc. Am., Washington.
Hower J. (1961) Some factors concerning the nature and origin of galuconite. Am. Miner. 46, 313-334.

Jarvis I. (1992) Sedimentology, geochemistry and origin of phosphatic chalks: the Upper Cretaceous deposits of NW Europe. Sedimentology, 39, 55-97.

Krajewsky K.P., Van Capellan P., Trichet J., Kuhn O., Lucas J., Martín-Algarra A., Prévôt L., Tewary V.C., Gaspar L., Knight R. \& Lamboy M. (1994) Biological controls and apatite formation in sedimentary environments. Eclog. Geol. Hel. 87, $701-745$.

Martín-Algarra A. \& Sánchez-Navas A. (1995). Phosphate stromatolites from condensed cephalopod limestones, Upper Jurassic, Southern Spain. Sedimentology, 42, 893-919.

Martín-Algarra A. \& Vera J.A. (1994) Mesozoic pelagic phosphate stromatolites from the penibetic (Betic Cordillera, southern Spain). Pp. 345-391 in: Phanerozoic Stromatolites II (J. Bertrand-Sarfati \& C. Monty, editors). Kluwer, Dordrecht.

Martínez-Ruiz F. (1993) Geoquímica y mineralogía del tránsito Cretácico-Terciario en las Cordilleras Béticas y en la Cuenca Vasco-Cantábrica. $\mathrm{PhD}$ thesis, Univ. Granada, Spain.

McArthur J.M. (1986) Francolite geochemistry-compositional controls during formation, diagenesis, metamorphism and weathering. Geochim. Cosmochim. Acta, 49, 23-35.

McRae S.G. (1972) Glauconite. Earth-Sci. Rev. 8, $397-440$.

Møller N. (1988) The prediction of mineral solubilities in natural waters: A chemical equilibrium model for the $\mathrm{Na}-\mathrm{Ca}-\mathrm{Cl}-\mathrm{SO}_{4}-\mathrm{H}_{2} \mathrm{O}$ system, to high temperature and concentration. Geochim. Cosmochim. Acta, 52, $821-837$.

Nieto L.M. (1996) La cuenca subbética mesozóica en el sector oriental de las Cordilleras Béticas. $\mathrm{PhD}$ thesis, Univ. Granada, Spain.

Odin G.S. (1975). De glauconarium constitutione, originae, aetateque. $\mathrm{PhD}$ thesis, Univ. Paris, France.

Odin G.S. \& Fullagar P.D. (1988) Geological significance of the glaucony facies. Pp. 227-294 in: Green Marine Clays. (G.S. Odin, editor). Developments in Sedimentology, 45. Elsevier, Amsterdam.

Odin G.S. \& Letolle R. (1980) Glauconitization and phosphatization environments: a tentative comparison. SEPM Sp. Pub. 29, 227-237.

Odin G.S. \& Matter A. (1981) De glauconiarum originae. Sedimentology, 28, 611-641.

Odom I.E. (1984) Glauconite and celadonite minerals. Pp. 545-572 in: Micas (S.W. Bailey, editor). Reviews in Mineralogy, 13. Mineral. Soc. Am., Washington.

Ostwald J. \& Bolton B.R. (1992) Glauconite formation as a factor in sedimentary manganese deposit genesis. Econ. Geol. 87, 1336-1344.

Prévôt L. \& Lucas J. (1986) Microstructure of apatite- 
replacing carbonate in sythesized and natural samples. J. Sed. Pet. 56, 153-159.

Rawlley R.K. (1994) Mineralogical investigations on an Indian glauconite sandstone of Madhya Pradesh state. Appl. Clay Sci. 8, 449-465.

Stille P. \& Clauer N. (1994) The process of glauconitization: chemical and isotopic evidence. Contrib. Mineral. Petrol. 117, 253-262.

Strickler M.E. \& Ferrell R.E. Jr. (1990) Fe substitution for $\mathrm{Al}$ in glauconite with increasing diagenesis in the first Wilcox sandstone (Lower Eocene), Livingston Parish, Louisiana. Clays Clay Miner. 38, 69-76.
Thompson R. \& Hower J. (1975) The mineralogy of glauconite. Clays Clay Miner., 23, 289-300.

Van Capellan P. \& Berner R.A. (1991) Fluorapatite crystal growth from modified seawater solutions. Geochim. Cosmochim. Acta, 55, 1219-1234.

Velde B. (1992) Introduction to Clay Minerals. Chapman \& Hall, London.

Vera J.A. \& Martín-Algarra A. (1994) Mesozoic stratigraphic breaks and pelagic stromatolites in the Betic Cordillera, Southern Spain. Pp. 319-344 in: Phanerozoic Stromatolites II (J. Bertrand-Sarfati \& C. Monty, editors). Kluwer, Dordrecht. 